\title{
Development and evaluation of a sesame thresher as influenced by crop, machine and operational parameters
}

\author{
B. Kailashkumar \\ Department of Farm Machinery and Power Engineering, Agricultural Engineering College and \\ Research Institute, Tamil Nadu Agricultural University, Kumulur - 621712 (Tamil Nadu), India \\ Email: kkailash35@gmail.com
}

\section{How to Cite}

Kailashkumar, B. (2021). Development and evaluation of a sesame thresher as influenced by crop, machine and operational parameters. Journal of Applied and Natural Science, 13 (SI), 172 - 178. https://doi.org/10.31018/jans.v13iSI.2824

\section{Article Info}

https://doi.org/10.31018/ jans.v13iSI.2824

Received: March 22, 2021

Revised: May 30, 2021

Accepted: June 14, 2021

\begin{abstract}
The development of a sesame thresher for the purpose has clearly an edge over conventional methods of threshing and reduce the drudgery of work to a great extent. Due to the scarcity of daily labours, it is essential to bring in a sesame thresher, which is cost-effective, compact, reduce threshing losses and easy to use for sesame cultivars. The laboratory experiments were conducted with different levels of variables, from that the combination level of $11.0 \mathrm{~ms}^{-1}$ peripheral velocity of threshing cylinder, $15 \mathrm{~mm}$ concave clearance, spike tooth type cylinder and $16.8 \%$ (d.b) moisture content of harvested sesame capsule were selected. The selected combination level yielding the maximum threshing efficiency of $99.0 \%$, maximum cleaning efficiency of $99.4 \%$ and minimum \% visible damage to threshed sesame grains of $0.79 \%$, was optimized for the development of prototype sesame thresher. A prototype sesame thresher consisting of a mainframe, threshing unit, blower and sieve assembly, feed chute, power transmission system and transport wheels was developed with optimized level of variables. The prototype sesame thresher was evaluated for its performance in comparison with the conventional method of sesame threshing. Compared with the manual method of threshing, the prototype sesame thresher resulted in 17,12 , and $1.2 \%$ savings in threshing efficiency, cleaning efficiency, and \% visible damage to threshed sesame grains. The prototype sesame thresher results in $87 \%$ and $83 \%$ saving in time and cost respectively when compared to the conventional method of manual threshing.
\end{abstract}

Keywords: Moisture content, Peripheral velocity, Prototype, Sesame, Thresher

\section{INTRODUCTION}

The traditional threshing operations for all the crops are most time-consuming, energy-intensive, labour intensive, drudgery-prone, and uneconomical (Naveenkumar et al., 2013; Abagisa et al., 2015 and Omale et al., 2015). The development of mechanical threshers for this purpose has clearly an edge over conventional methods and has reduced the drudgery of work to a great extent (Singh et al., 2015; Patil et al., 2016). These stationary threshing machines are based on the quick process, level of performance, reduction of the drudgery of farmers/labours, improved quality of product and economy. With the existing socioeconomic condition of sesame cultivars, the large capacity threshers are inappropriate, and even small-sized threshers with large scale sophistication are difficult to adopt. A worldwide number of studies have been done for the thresh- ing of various crops, but a few studies have been reported on sesame threshing. Keeping the above facts in view, the research work was carried out to identify the pertinent variables that influence the design of sesame thresher. The experimental sesame thresher test rig were made for investigating the interactive effect of selected levels of variables on the performance under laboratory conditions. The optimization of the selected levels of variables were taken for achieving the desired performance of sesame thresher. From that, the development of a prototype sesame thresher with optimized levels of variables and evaluation of the performance of the prototype sesame thresher was done.

\section{MATERIALS AND METHODS}

The conventional method of sesame threshing includes heaping of the harvested sesame stalks for curing for 
three days, initial shaking of cured sesame stalks, subsequent drying for one more day and shaking of stalks and manual beating of sesame stalks to separate the remaining grains from stalk. The total cultivated area, production and productivity of sesame in Tamil Nadu are 33181 ha, 17179 tonnes and $518 \mathrm{~kg} \mathrm{ha}^{-1}$ respectively (Department of Economics \& Statistics, India, 2014). Among the predominant varieties (TMV 3, TMV 4, TMV 6, TMV 7, CO 1, VRI (SV) 1, SVPR1, VRI (SV) 2) of sesame cultivated in Tamil Nadu, the popular variety TMV- 4 in the study region is selected for the investigation.

\section{Identification of pertinent crop parameters}

The pertinent crop parameters relevant to the development of functional components of sesame thresher were identified. The mean effective length of sesame stalk of $600 \mathrm{~mm}$ was used to arrive at the concave length of $600 \mathrm{~mm}$ in the threshing unit of the experimental sesame thresher. The mean value of the width of the sesame capsule of $5.65 \mathrm{~mm}$ was used to fix the mesh size of the concave as $5 \mathrm{~mm}$. The thousand-grain weight of sesame and the weight of grains per capsule were used for the calculation of the total weight of the sesame grains input for the experimental sesame thresher. For retention of sesame capsule in the top sieve, the sieve hole for the top screen was fixed as 20 $\mathrm{mm}$ and for sesame capsules to through the bottom sieve; the size of the hole for the bottom sieve was fixed as $3.5 \mathrm{~mm}$. The mean values of bulk density of selected sesame seeds were $0.651 \mathrm{~kg} \mathrm{~m}^{-3}$ and the value was used for the selection of size of the grain collection tray of experimental sesame thresher.

The grain outlet tray was made of mild sheet metal due to the lower frictional angle and coefficient of friction between sesame grains and metal. The inclination of the grain collection tray was fixed as $40^{\circ}$ (more than the angle of repose of sesame grains of $30^{\circ}$ ) to facilitate easy flow of sesame grains.

\section{Selection of machine variables}

The pertinent variables that influence the development of sesame thresher were identified and levels of varia- bles were selected. The interactive effect of selected levels of variables viz., peripheral velocity of the threshing cylinder $\left(7.9,11.0\right.$ and $\left.14.1 \mathrm{~ms}^{-1}\right)$, concave clearance $(10,15$ and $20 \mathrm{~mm})$, type of threshing cylinder (wire loop, spike tooth and rasp bar) as shown in Fig.1 and moisture content (d.b.) of harvested sesame capsule $21.4,16.8$ and $15.1 \%$ as shown in Fig.2 was investigated on threshing efficiency, cleaning efficiency and $\%$ damage caused to the threshed sesame grains using an experimental sesame thresher test rig under laboratory condition.

A total number of 243 treatments under laboratory condition were conducted with selected levels of variables viz., of the peripheral velocity of the cylinder $(7.9,11.0$ and $\left.14.1 \mathrm{~ms}^{-1}\right)$, concave clearance (10, 15 and 20 $\mathrm{mm}$ ), types of the threshing cylinder (wire loop, spike tooth and rasp bar) and moisture content of harvested sesame capsule (21.4, 16.8 and 15.1 d.b). From the recorded observations, the threshing efficiency, cleaning efficiency and \% visible damage to threshed sesame grains were computed.

The threshing effectiveness of the experimental sesame thresher was affected highly by the moisture content of harvested sesame capsule followed by the type of threshing cylinder, the peripheral velocity of the threshing cylinder, and the concave clearance. The combination level of $11.0 \mathrm{~ms}^{-1}$ peripheral velocity of the threshing cylinder, $15 \mathrm{~mm}$ concave clearance, spike tooth type cylinder and $16.8 \%$ (d.b) moisture content of harvested sesame capsule yielded the maximum threshing efficiency of $99.0 \%$, maximum cleaning efficiency of $99.4 \%$ and minimum $\%$ visible damage to threshed sesame grains of $0.79 \%$, is optimized for the development of prototype sesame thresher.

\section{Development of sesame thresher}

A prototype sesame thresher was developed with optimized levels of variables. The prototype sesame thresher drawn using 3D CAD software is shown in Fig.3. The prototype sesame thresher consists of a mainframe, threshing unit, blower and sieve assembly, feed chute, power transmission system and transport wheels, as shown in Fig.4.
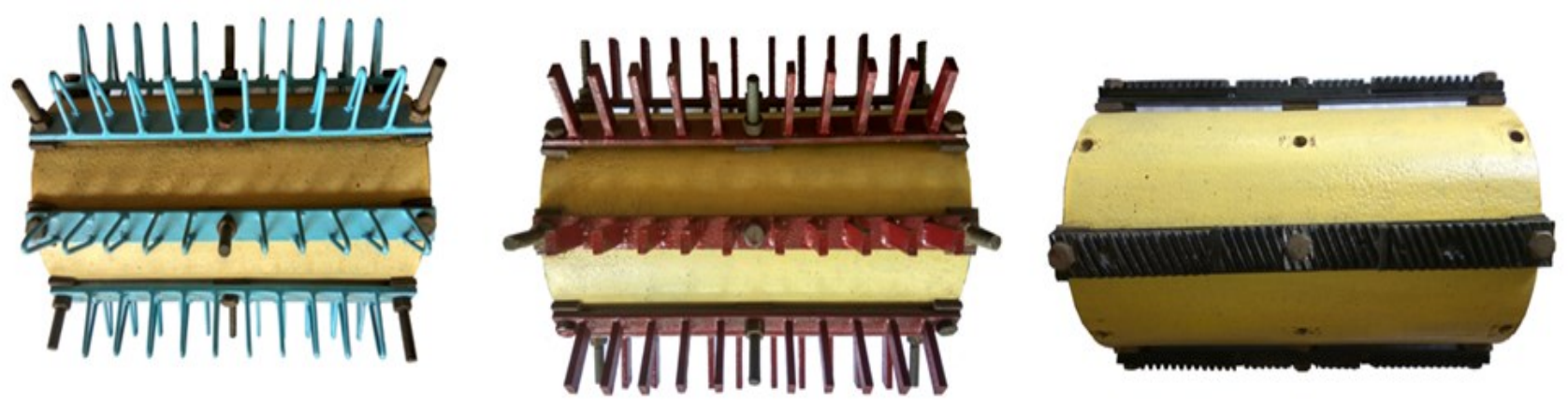

Fig. 1. Threshing cylinder (wire loop, spike tooth and rasp bar). 
The mainframe was a welded rectangular box structure of size $1140 \times 910 \times 1130 \mathrm{~mm}$. It was made by using $50 \times 50 \times 5 \mathrm{~mm}$ mild steel ' $\mathrm{L}$ ' angle iron section. All the other functional components were attached to the mainframe. The mainframe supports the entire weight of the machine. The feed chute was the component on which the harvested sesame crop was placed and fed into the threshing cylinder. It was made of $1.3 \mathrm{~mm}$ mild steel sheet. The feed chute was fixed at an inward inclination of $30^{\circ}$ to facilitate the easy feeding of harvested sesame crop in to the threshing cylinder. The chute was trapezoidal section of $600 \mathrm{~mm}$ length, $355 \mathrm{~mm}$ width and $255 \mathrm{~mm}$ height. The feed chute opening at the outer end and cylinder end was $600 \times 255 \mathrm{~mm}$ and $600 \times 155 \mathrm{~mm}$, respectively. The feeding chute was fixed at $1165 \mathrm{~mm}$ height from the ground level for safety and easy feeding.

The threshing unit included the optimized type of threshing cylinder and concave. The diameter and length of the hollow threshing cylinder was 300 and $600 \mathrm{~mm}$ respectively. It was made of $1.2 \mathrm{~mm}$ mild steel sheet metal. The upper half of the threshing unit was enclosed with semicircular shield made of $2 \mathrm{~mm}$ mild steel sheet metal. The shaft of made of $50 \mathrm{~mm}$ mild steel rod was fixed at the center of the threshing drum and the two ends of the shaft rest on plumber block

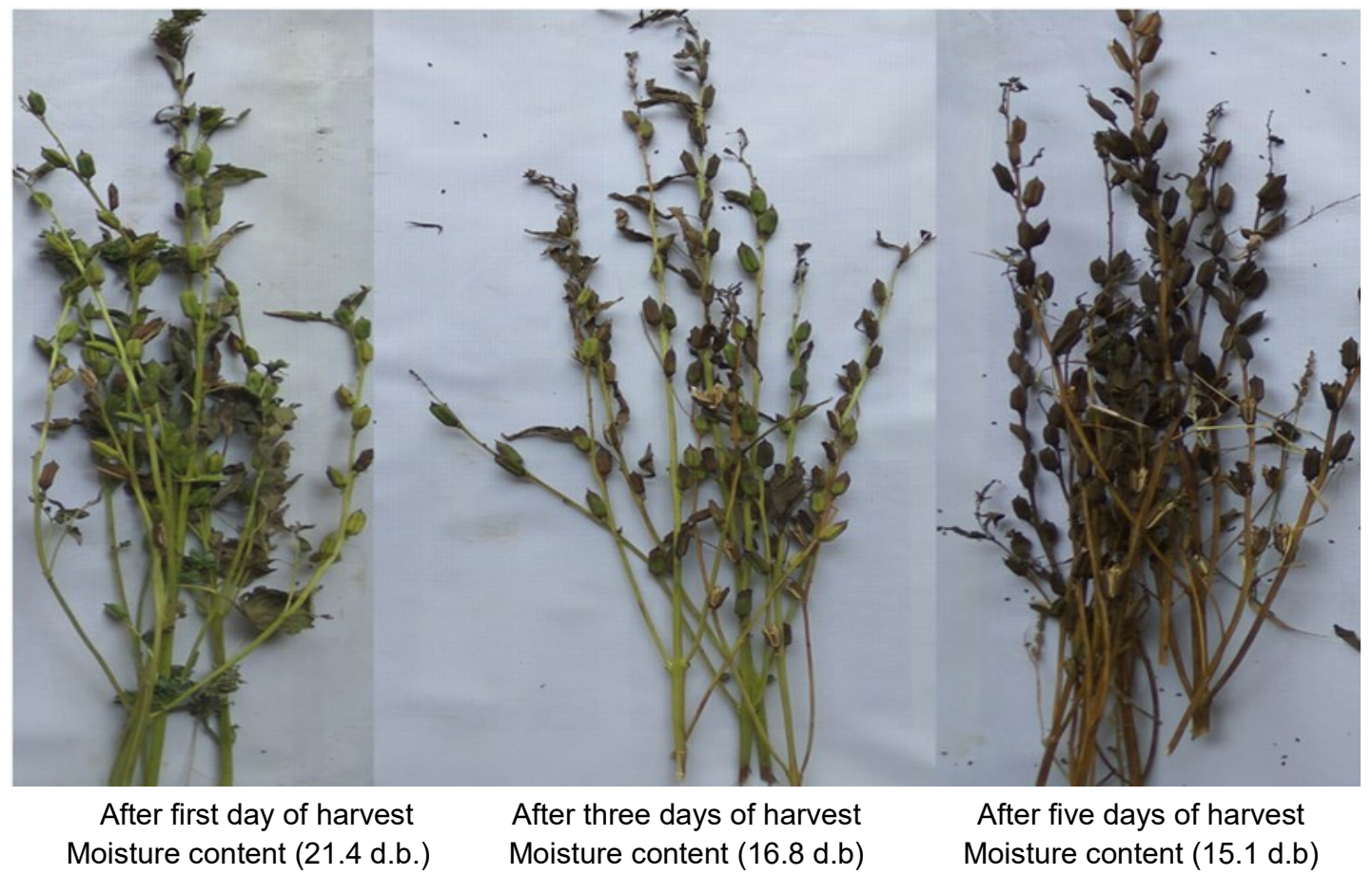

Fig. 2. Harvested sesame stalks with capsules after curing and drying.

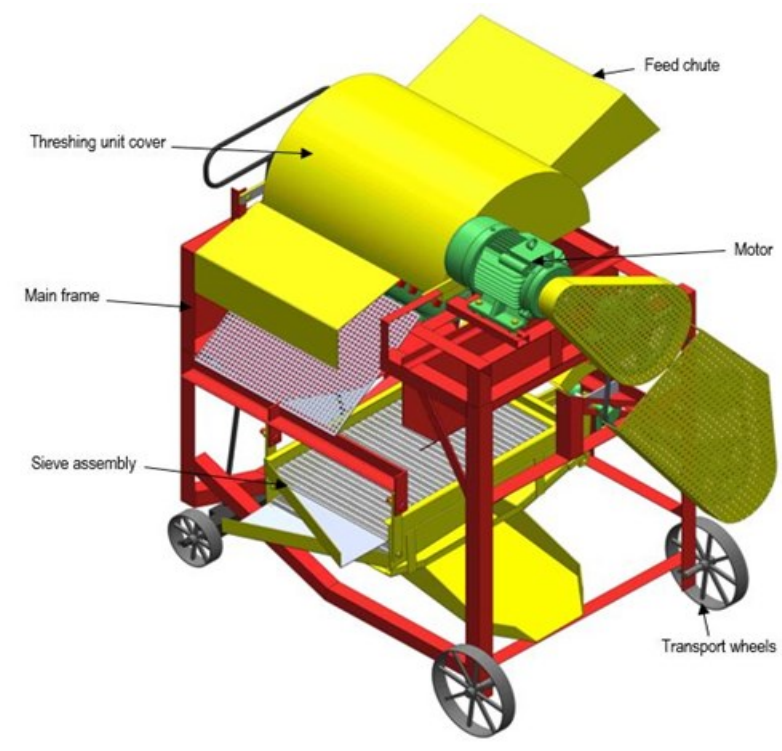

Fig. 3. Sesame thresher - 3D CAD Design.

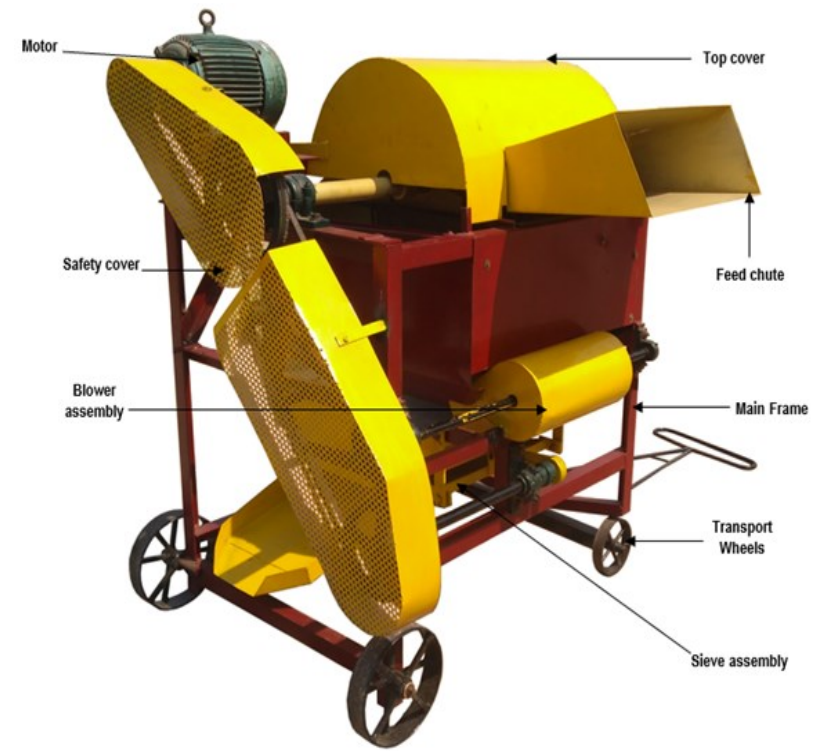

Fig. 4. Prototype sesame thresher. 
bearings mounted on the mainframe. For power transmission, a $150 \mathrm{~mm}$ diameter ' $\mathrm{V}$ ' pulley was fixed on the shaft at one end.

It was a curved unit fitted below the threshing cylinder. The concave near the feeding end was hinged at both ends and connected to a slot with necessary supports to the mainframe. The concave type corresponding to the optimized threshing cylinder type was fitted. The concave clearance was fixed at the optimized level of laboratory investigation. The cleaning unit consists of the blower, sieve and outlet tray.

The blower was made of $1.6 \mathrm{~mm}$ mild steel sheet metal work. The blower housing was nautilus shaped with a major diameter of $200 \mathrm{~mm}$, a width of $340 \mathrm{~mm}$ and a length of $430 \mathrm{~mm}$. The inner diameter for the air inlet was $80 \mathrm{~mm}$ and the throat of the blower housing is 430 $x 50 \mathrm{~mm}$ in size. The blower fan was made up of four paddle blades of $1.3 \mathrm{~mm}$ gauge mild steel metal sheet dimensioned $400 \times 55 \mathrm{~mm}$ bolted to a $28 \mathrm{~mm}$ diameter shaft. The blower outlet was directed towards the sieve shaking mechanism to blow out the chaff and dust from grains. The two ends of the shaft rest on pillow block bearings mounted on the mainframe. For power transmission, a $150 \mathrm{~mm}$ diameter 'V' pulley was fixed on the shaft at one end.

The threshers were equipped with two sieves of perforated sheets having rectangular slots. The top sieve was provided so as not to pass the chaffs to the bottom sieve. The top sieve was made up of 1.6 $\mathrm{mm}$ mild steel sheet metal of $520 \times 790 \mathrm{~mm}$ with each slot size of $20 \times 5 \mathrm{~mm}$. The bottom sieve sieves out small sesame grains and delivers the clean grain towards outlet. It was made of $1.6 \mathrm{~mm}$ mild steel sheet metal of $520 \times 790 \mathrm{~mm}$ with a rec-

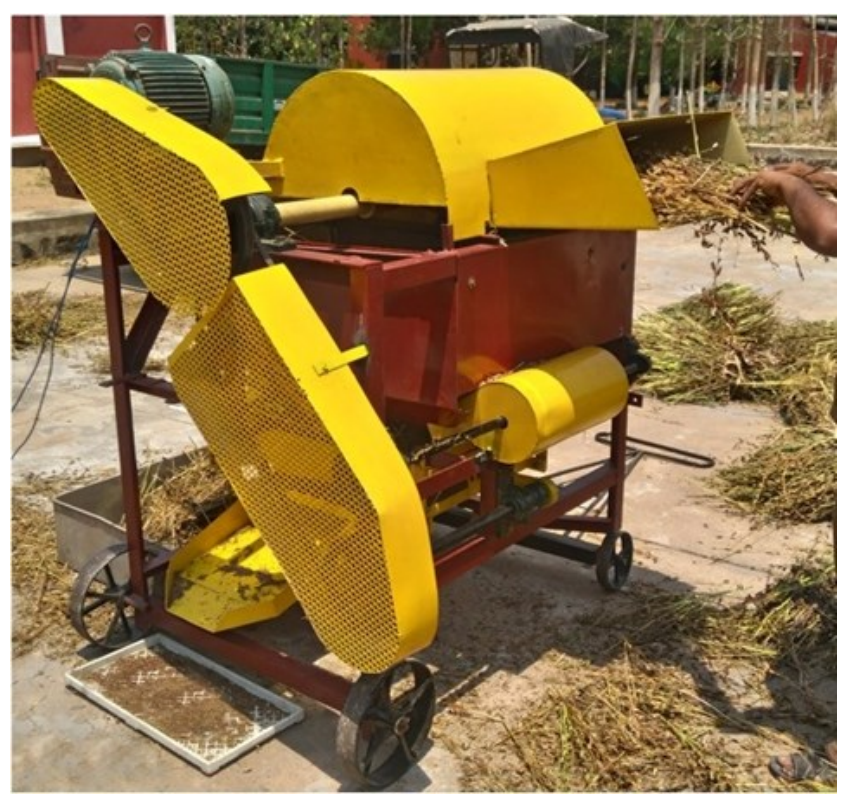

Fig. 5. Operational view of sesame thresher. tangular slot hole of $35 \times 3 \mathrm{~mm}$. The size of the sieve hole is $3.5 \mathrm{~mm}$. The lower sieve was placed $65 \mathrm{~mm}$ below the top sieve.

The upper and lower sieves were placed in a rectangular tray of $520 \times 790 \mathrm{~mm}$ made of $1.6 \mathrm{~mm}$ mild sheet metal. These sieves were oscillated or shaken with a crank attached to the trays. The crank was attached to a cam pulley having slot length of $30 \mathrm{~mm}$ in which the circular motion was converted into oscillating motion of sieve. For power transmission, a $200 \mathrm{~mm}$ diameter 'V' pulley is fixed on the shaft at one end.

The grain outlet was a rectangular tray of $980 \times 415$ $\mathrm{mm}$ made of $1.6 \mathrm{~mm}$ mild sheet metal and fitted with a bottom sieve at an inclination of $40^{\circ}$ to facilitate easy flow of sesame grains. The thresher was provided with four wheels, two in the front and two in the rear portion for easy transportation. These wheels are made with $2.6 \mathrm{~mm}$ mild steel sheet metal rolled to circular wheels of $300 \mathrm{~mm}$ diameter and $50 \mathrm{~mm}$ width at the rear and $200 \mathrm{~mm}$ diameter and $40 \mathrm{~mm}$ width at the front. The wheels are attached to the axle, which was attached to a handle for moving the unit.

The prime mover was a two hp single phase electric motor (1440 rpm) mounted on one side of the top corner of the mainframe with the necessary support. The power was transmitted from the motor to the threshing cylinder shaft, blower shaft, sieve shaker shaft through a V-belt and pulley arrangement.

The specifications of prototype sesame thresher are furnished in table 1.

\section{RESULTS AND DISCUSSION}

The operational view of sesame thresher is shown in Fig. 5. The performance of developed prototype sesame thresher compared with the conventional method of threshing was carried out and the observations viz., weight of grain, weight of chaff, weight of sesame stalk after threshing were recorded. From the recorded observations, the threshing efficiency, cleaning efficiency and \% visible damage to sesame grains were computed and compared with the conventional method. From the measured observations during the evaluation of prototype, sesame thresher, the cost of operation of the developed prototype sesame thresher was computed and compared with manual threshing. The saving in cost, time and labour computed for the developed prototype sesame thresher in comparison the traditional method of sesame threshing were as follows:

The cost of threshing by manual method are computed as detailed below.

No. of men labours required for manual threshing $=5(480 \mathrm{~kg})$

Man hours required to thresh $480 \mathrm{~kg}$ of crop stalks 
$=3$ hours

Cost of threshing @Rs. 50/man/hour=5 x $50 \times 3$

$$
=\text { Rs. } 750 / 480 \mathrm{~kg} \text {. }
$$

The cost of mechanical threshing are computed as detailed below.

No. of men labours required for threshing $=2(480 \mathrm{~kg})$

Man hours required to thresh $480 \mathrm{~kg}$ of crop stalks

$$
=1 \text { hour }
$$

Cost of threshing @Rs. 50/man/hour = 2x $50 \times 1$

$=\mathrm{Rs} .100 / 480 \mathrm{~kg}$.

Initial cost of prototype sesame thresher (P), Rs. 30,000

Salvage cost $10 \%$ of initial cost (S), Rs. 3000

Expected life period of thresher $(L)$, years - 8

Annual working hours $(A)$, hours per year - 312.5

Rate of interest (I), \%

$-14$

\section{i. Fixed cost of operation of sesame thresher}

$\begin{array}{ll}\text { Depreciation, Rs. } \mathrm{h}^{-1} & =\frac{P-S}{L \times A}=10.8 \\ \text { Interest, Rs. } \mathrm{h}^{-1} & =\frac{P+S}{2} \times \frac{I}{100 \times A}=7.392\end{array}$

Taxes, Insurance and housing $(2 \%$ of the initial cost of thresher), Rs. $h^{-1}=1.92$

Fixed cost of operation of Thresher, Rs. $\mathrm{h}^{-1}$

$($ Depreciation + Interest $+\mathrm{TIH})=10.8+7.39+1.92$

$$
=20.11
$$

\section{ii. Variable cost of operation of prototype sesame thresher}

Cost of electricity one unit $=7$

Output power of $2 \mathrm{HP}=(2 \times 0.746) \mathrm{kW}=1.49 \mathrm{~kW}$.

Unit consumed $=$ Power in $\mathrm{kW} \times$ Number of hours of operation.

$=1.49 \times 1$

$=1.49$

Electricity cost, Rs. $\mathrm{h}^{-1} \quad=1.49 \times 7$

$$
=10.43
$$

Total cost of operation, Rs. $h^{-1}=20.11+10.43$

$$
=30.54
$$

Total cost of threshing $=$ (fixed cost + variable cost + operator cost) $=20.11+10.43+100=130.54$

(Fixed and variable cost are calculated as per IS: 91641979, Guide for estimating cost of farm machinery operation.)

Cost saved over manual threshing $=750-130.54$

$$
=\text { Rs.619.46 }
$$

Saving in cost of threshing with prototype sesame thresher when compared to manual method of threshing $=((750-130.54) \times 100) / 750$

$$
=82.59 \%=83 \%
$$

Saving in time of threshing with prototype sesame thresher when compared to manual method of threshing $=((15-2) \times 100) / 15$

$$
=86.6 \%=87 \%
$$

The comparative evaluation of prototype sesame thresher with the conventional method of threshing is furnished in table 2 .

Farmers face lot of production constraints which include high cost of labour, non-availability of quality seeds etc. whereas they are also not using improved technologies and high yielding varieties. Due to uneven maturity of pods, seasonality in production and poor post-harvest practices, the post-harvest losses were also high, thus reducing further availability of sesame for consumption and value addition. The traditional methods of threshing operations are most time consuming, energy intensive, labour intensive, drudgery prone and uneconomical (Naveenkumar et al., 2013 and Omale et al., 2015). The development of mechanical threshers for this purpose has clearly an edge over conventional methods and has reduced the drudgery of work to a great extent (Singh et al., 2015 and Patil et al., 2016). The important parameters which influence the threshing efficiency are mechanical damage, moisture content, threshing cylinder speed, feeding rate and concave clearance (Naveenkumar et al., 2013 and Timothy Adesoye Adekanye., 2016). The speed of threshing cylinder and moisture content had significant effect on threshing efficiency and damaged grain percentage (Khazaei, 2003). The performance of the unit has been evaluated in terms of threshing efficiency, cleaning efficiency, and seed damage (Kepner et al., 1978, Ajayi et al., 2014, Munusamy et al., 2015, and Olaye et al., 2016)

In present study, a prototype sesame thresher developed with optimized levels of variables is cost effective, compact and easy to use for sesame cultivars. Compared with the manual method of threshing, the prototype sesame thresher resulted in 17, 12 and 1.2 $\%$ saving in threshing efficiency, cleaning efficiency, and $\%$ visible damage to threshed sesame grains. The prototype sesame thresher resulted in 87 and 83 $\%$ saving in time and cost respectively when compared to the conventional method of manual threshing.

\section{Conclusion}

The combination level of $11.0 \mathrm{~ms}^{-1}$ peripheral velocity of threshing cylinder, $15 \mathrm{~mm}$ concave clearance, spike tooth type threshing cylinder and $16.8 \%$ (d.b) moisture content of sesame capsule was adjudged as the optimized level for the development of prototype sesame thresher as it yielded the maximum threshing efficiency of $99.0 \%$, maximum cleaning efficiency of $99.4 \%$ and minimum \% damage caused to threshed sesame grains of $0.79 \%$. A prototype sesame thresher consisting of a main frame, threshing unit, blower and sieve assembly, feed chute, power transmission system and transport wheels 
Table 1. Specifications of prototype sesame thresher.

\begin{tabular}{|c|c|c|}
\hline S.No. & Details & Values \\
\hline A & Overall dimensions $(\mathrm{Lx} B \times \mathrm{W}), \mathrm{mm}$ & $1140 \times 910 \times 1035$ \\
\hline B & Type of thresher & Throw-in \\
\hline C & Threshing unit & \\
\hline i & Type of threshing cylinder & Spike tooth \\
\hline ii & Diameter of the drum, $\mathrm{mm}$ & 300 \\
\hline iii & Length of the drum, $\mathrm{mm}$ & 600 \\
\hline iv & Concave clearance, $\mathrm{mm}$ & 15 \\
\hline $\mathrm{v}$ & Peripheral velocity of threshing cylinder, $\mathrm{ms}^{-1}$ & 11.0 \\
\hline $\mathrm{D}$ & Power required & $2 \mathrm{hp}$ single phase electric motor \\
\hline$E$ & Cleaning unit & \\
\hline i & Type of blower & Centrifugal type \\
\hline ii & No. of blades & 4 \\
\hline iii & Length of blade, $\mathrm{mm}$ & 400 \\
\hline iv & Width of blade, $\mathrm{mm}$ & 55 \\
\hline$v$ & Number of sieves & 2 \\
\hline $\mathrm{F}$ & Feed chute & \\
\hline i & Shape & Trapezoidal \\
\hline ii & Size at the feeding end, $\mathrm{mm}$ & $600 \times 255$ \\
\hline iii & Size at the cylinder end, $\mathrm{mm}$ & $600 \times 155$ \\
\hline G & Power transmission & V- belt and pulley \\
\hline $\mathrm{H}$ & Transport wheels & Four iron wheels \\
\hline
\end{tabular}

Table 2. Results of comparative evaluation of prototype sesame thresher with the conventional method of threshing comparison of sesame thresher with manual threshing.

\begin{tabular}{llll}
\hline S.No. & Parameters & $\begin{array}{l}\text { Conventional method } \\
\text { of sesame threshing }\end{array}$ & $\begin{array}{l}\text { Threshing with prototype } \\
\text { sesame thresher }\end{array}$ \\
\hline i & Threshing efficiency, $\%$ & $82 \%$ & $99 \%$ \\
ii & Cleaning efficiency, $\%$ & $87 \%$ & $99 \%$ \\
iii & $\%$ visible damage to threshed sesame grains, & $2 \%$ & $0.79 \%$ \\
vi & $\%$ & Minimum 5 & Maximum 2 \\
& Number of workers required & & 2 \\
v & Time consumed to thresh $120 \mathrm{~kg}$ of sesame & 15 & $130.54^{* *}$ \\
& grains, man ${ }^{-1}$ & & \\
vi & Cost of operation of threshing sesame grains, & $750^{*}$ & \\
\end{tabular}

* Cost of threshing by manual method ** Cost of threshing by mechanical method 
developed with optimized levels of variables is cost-effective, compact and easy to use for seasame cultivars.

\section{ACKNOWLEDGEMENTS}

I have immense pleasure to express my deep sense of gratitude and indebtedness to beloved Professors, Dr. K. Kathirvel, (Retd.) and Dr. D. Asokan, (Retd.) for their exemplary guidance, incessant inspiration, immense patience, efficacious advice, perpetual and criticisms evinced throughout the research work. I am greatly indebted to the Tamil Nadu Agricultural University for providing an opportunity to undergo this research work at Agricultural Engineering College and Research Institute, Kumulur. Words are inadequate to express my heartfelt gratitude to my beloved parents Mr. P. Balasubramaniyam and Mrs. B. Sundaravalli and my sister Ms. B.S. Keerthana for their everlasting love, affection, help, support, incessant motivation and constant encouragement throughout my research work.

\section{Conflict of interest}

The author declares that he has no conflict of interest.

\section{REFERENCES}

1. Department of Economics and Statistics (2014). Department of Economics and Statistics, Tamil Nadu, India.

2. Abagisa, H., Tesfaye, T. \& Befikadu, D. (2015). Modification and testing of replaceable drum multi-crop thresher. International Journal of Sciences: Basic and Applied Research (IJSBAR), 23(1), 242-255

3. Ajayi, B., Buliaminu Kareem, Olanrewaju, R. Bodede \& Oluwasiji, F. Adeoye (2014). Comparative quality and performance analysis of manual and motorised traditional portable rice threshers. Innovative Systems Design and
Engineering, 5(4), 1 - 6.

4. Kepner, R.A., Bainer, R. \& Barger, E.L. (1982). Principles of Farm Machinery. 3rd Edition, AVI Publishing, INC., Westport.

5. Khazaei, J. (2003). Determining the force requirement for pullingoff chickpea pods as well as fracture resistance of chickpeapods and grains. PhD. Thesis, Department of Agricultural Machinery, Tehran University, Iran.

6. Munusamy. P, Pandiselvam Ravi, Kailappan Ramasamy and John Kennedy Zachariah. (2015). Effect of feed rate, concave clearance and peripheral speed on the performance evaluation of pre thresher for onion umbels (Allium cepa var. aggregatum L.) Scientific Journal Agricultural Engineering Year $X L$, (3), 13-22.

7. Naveen Kumar, D.B., Kumar, Prasanna, Arun Kumar, H.S., Sandeep, T.N. \& Sudhadevi, G. (2013). Efficiency of mechanical thresher over traditional method of threshing finger millet. Internat. J. Agric. Engg., 6 (1), 184-188.

8. Olaye, A.R., Biaou, I., Moreira, J., Hounhouigan, J. \& Amponsah, S. K. (2016). Effect of threshing drum speed and crop weight on paddy grain quality in axial- flow thresher. Journal of Multidisciplinary Engineering Science and Technology (JMEST) 3,(1), 3716 - 3721.

9. Omale, J.O., Onum, E. \& Odeh, S.A. (2015). Design and construction of African yam bean thresher. International Journal of Current Research in Life Sciences, 4 (11), 446448.

10. Patil, K., Shamuvuel, Pandit, Gajendra, Pol., Sunil Kadam \& Avdhut Jadhav (2016). Design and fabrication of corn shelling and Threshing Machine. International Journal of Innovative Research in Science, Engineering and Technology, 5(7), 13981-13986.

11. Singh, K. P., Poddar, R. R., Agrawal, K. N., Hota, S. \& Singh, M. K. (2015). Development and evaluation of multi millet thresher. Journal of Applied and Natural Science, 7 (2), 939-948.

12. Timothy Adesoye Adekanye (2016). Evaluation of a soybean threshing machine for small scale farmers. Agricultural Engineering International : The CIGR E-Journal, 18 (2), $426-434$. 